\title{
YEAR CYCLE AND MORPHOMETRICAL CHARACTERISTICS OF AUSTROPOTAMOBIUS TORRENTIUM FROM TWO KARSTIC RIVERS IN CROATIA
}

\author{
Leopoldina Dakić ${ }^{1} \&$ Ivana Maguire ${ }^{2}$ \\ ${ }^{1}$ Public institution NATURA VIVA for managing protected natural resources \\ of the Karlovac County, Croatia \\ ${ }^{2}$ University of Zagreb, Faculty of Science, Department of Biology, Rooseveltov trg 6, \\ 10000 Zagreb, Croatia (++385 148777 41, imaguire@zg.biol.pmf.hr)
}

Dakić, L. \& Maguire, I.: Year cycle and morphometrical characteristics of Austropotamobius torrentium from two karstic rivers in Croatia. Nat. Croat., Vol. 25, No. 1, 87-100, 2016, Zagreb.

Stone crayfish (Austropotamobius torrentium) is one of the four native European crayfish species inhabiting Croatian freshwaters and is protected by Croatian law. The aim of this work was to investigate several aspects of species life cycle, morphometrics and habitat preferences. Populations were studied for 18 months in two streams in the Karlovac County. Crayfish were trapped once a month. Altogether 806 crayfish were analysed and their weight plus 7 morphometric characteristics per crayfish were recorded. Eight different physicochemical parameters of the water were measured. We found positive correlations between the number of captured individuals and water temperature, conductivity and water hardness. A negative correlation was found between the number of captured individuals and water level. The maximal recorded weight was $72 \mathrm{~g}$ for males and $43 \mathrm{~g}$ for females, while the maximal recorded body length was $11.02 \mathrm{~cm}$ for males and $10.37 \mathrm{~cm}$ for females. Freshly moulted animals were caught from June to November. Development of the glair glands started in July, external eggs were recorded from November to June and newly hatched juveniles were caught in June and July. The smallest egg-bearing female was $6.42 \mathrm{~cm}$ long. Males and females differed significantly in all measured morphometric characteristics and body weight, while crayfish from the two populations differed significantly in carapace width, claw length, claw width and claw height in males and in total body length, carapace width, claw height and width of the first abdominal pleura in females. It could be assumed that observed morphological differences between populations occurred due to crayfish adaptation to specific local environmental and ecological conditions.

Key words: stone crayfish; year cycle; morphometrics; Croatia

Dakić, L. \& Maguire, I.: Godišnji ciklus i morfometrijske karakteristike vrste Austropotamobius torrentium iz dviju krških rijeka u Hrvatskoj. Nat. Croat., Vol. 25, No. 1, 87-100, 2016, Zagreb.

Potočni rak (Austropotamobius torrentium) jedna je od četiri europske vrste deseteronožnih rakova iz porodice Astacidae koja živi u hrvatskim slatkovodnim ekosustavima te je strogo zakonom zaštićena. Cilj ovog rada bio je istražiti nekoliko aspekata životnog ciklusa vrste, njenu morfometriju i uvjete staništa. Populacije su istraživane tijekom 18 mjeseci u dva potoka u Karlovačkoj županiji. Životinje su lovljene jednom mjesečno. Ukupno je ulovljeno 806 jedinki kojima je zabilježen spol, faza presvlačenja i reprodukcije, izmjereno je sedam morfometrijskih obilježja i težina tijela. Pri svakom uzorkovanju izmjereno je osam fizikalno-kemijskih parametara vode. Zabilježena je pozitivna korelacija između broja ulovljenih jedinki i temperature, vodljivosti i ukupne tvrdoće vode. Negativna korelacija zabilježena je između broja ulovljenih jedinki i razine vode. Maksimalna zabilježena težina tijela iznosila je $72 \mathrm{~g}$ kod mužjaka i $43 \mathrm{~g}$ kod ženki, dok je maksimalna zabilježena dužina tijela iznosila 11,02 cm kod mužjaka i 10,37 cm kod ženki. Svježe presvučene životinje lovljene su od lipnja do studenog. Razvoj 
cementnih žlijezda započeo je u srpnju, vanjska jaja bilježena su od studenog do lipnja, a tek izlegli juvenilni rakovi zabilježeni su u lipnju i srpnju. Najmanja ženka s pleopodalnim jajima bila je duga $6,42 \mathrm{~cm}$. Mužjaci i ženke razlikuju se značajno u svim mjerenim morfometrijskim obilježjima i težini tijela, dok se jedinke iz dviju populacija međusobno značajno razlikuju u širini karapaksa, dužini, širini i debljini kliješta kod mužjaka te ukupnoj dužini tijela, širini karapaksa, debljini kliješta i širini prve abdominalne pleure kod ženki. Možemo pretpostaviti da su zabilježene morfometrijske razlike između populacija posljedica adaptacije na specifične stanišne i ekološke uvjete.

Ključne riječi: potočni rak, godišnji ciklus, morfometrija, Hrvatska

\section{INTRODUCTION}

The stone crayfish Austropotamobius torrentium (Schrank, 1803) is one of the four native European crayfish species from the family Astacidae inhabiting Croatian freshwater habitats. It is protected by Croatian law (NArodne Novine 80/13) and Regulation on strictly protected species (NAROdne Novine 144/13). It is also included in the Croatian Red list of fresh and brackish water crustacean and categorized as a vulnerable species (VU) (GotTstein et al., 2011).

Distribution of freshwater crayfish in Croatia has been well studied by several authors (Maguire, 2002; Maguire \& GotTstein-Matočec, 2004; Maguire et al., 2006, 2011), but there is still a lack of data on ecology and morphometrical features of the species. $\mathrm{Au}$ stropotamobius torrentium is naturally distributed in the continental part of Croatia in the water bodies of the Black Sea drainage, with only a few recorded populations within the streams of the Adriatic Sea drainage (Karaman, 1929; Albrecht, 1982; Maguire et al., 2011). Most probably, the species spread from Black Sea drainage into the Adriatic Sea drainage during the geological past when the two drainages were connected (ŽGANEC, 2009). Existing populations are remnants of the more widely distributed historical populations which were devastated by the disease crayfish plague at the end of $19^{\text {th }}$ and during $20^{\text {th }}$ century (ŠULGAJ, 1937; BuDiHNA, 1991). Also, water pollution, watercourse regulation and riverside vegetation removal as well as the consequences of extreme droughts strongly affect abundance and distribution of the A. torrentium populations. Comparing historical and recent data, Maguire et al. (2011) found the apparent decline in number of the stone crayfish populations in Croatia.

Austropotamobius torrentium mainly inhabits headwater sections of small, fast running brooks (Kappus et al.,1999), but also forms lake populations (RENZ \& BREITHAUpt, 2000). Coexistence with other crayfish species (Astacus astacus, Astacus leptodactylus, Austropotamobius pallipes) has been observed (BоHL, 1987; SтUскі \& RöMER, 2001; STLOUKal \& HarváneKová, 2005; Sint et al., 2006; Vlach et al., 2009; PÂrvulescu et al., 2011). Degree to which the distribution areas of two species overlaps depends mainly on their preference for the specific habitat type (BоHL, 1987; STUCKI \& RöMER, 2001). The most important factor determining the crayfish choice of habitat is the bottom substrate (CAPELLI \& MAGNusson, 1975; LodGE \& HILl, 1994), which for the stone crayfish is indicated by its name - stony substrate. Abundance of Austropotamobius torrentium populations in a certain habitat is proportional to the relative amount of shelters (stones, tree roots) into which crayfish can retreat during the daylight hours, to avoid predation or to prevent drift (Schulz \& Kirchlehner, 1984; Streissl \& HöDl, 2002a; Maguire et al., 2002). The physical and chemical characteristics of the water are also important factors influencing population density and crayfish activity during the year (MAguire et al., 2002). Stone crayfish is very sensitive to water pollution (MACHINO \& FÜREDER, 2005) and prefers habitats with good water quality. 
Animals tend to adapt to their specific environment both in genotype and phenotype (Swain \& Foote, 1999). Existence of specific stocks within certain species may be a consequence of either genetic differentiation or morphological variation of the same genotype (PAKKasma, 2001; ImRe et al., 2002), but mostly combination of both mechanisms can be expected (IMre et al., 2002). Phenotypic differences may indicate beginning of stock differentiation during which the genotype has not yet changed. Therefore, morphological differences might be more suitable for analysis of short-term effects and ongoing differentiation (BEGG et al., 1999). Morphometric measurements are very often used to explore differences between crayfish species and populations (GrANDJEAN et al., 1997a; Grandjean et al., 1997b; Grandjean \& Souty-Grosset, 2000; Sint et al., 2005; Maguire et al., 2006; Sint et al., 2006; Sint et al., 2007; Maguire \& DAKIĆ, 2011). Problems with using morphometry as a tool for distinguishing populations or species may arise from variations in the absolute size of individuals. That is why all linear measurements should be normalized by conversion to specific ratio expressions (CHAMBERs et al., 1979).

The aim of this work was to investigate several aspects of species life cycle, morphometrics and habitat parameters and to contribute to the knowledge of the ecology of $A$. torrentium populations, which are still widely distributed in karstic rivers of the Karlovac County.

\section{MATERIAL AND METHODS}

Populations of A. torrentium were studied from May 2010 to October 2011 in two streams in the Karlovac County: Komadinski potok (Plaški site; 45 $03^{\prime} 43.55^{\prime \prime} \mathrm{S}$, $15^{\circ} 23^{\prime} 15.21^{\prime \prime} \mathrm{I}, 406 \mathrm{~m}$ a.s.1.) near Plaški and unnamed stream in Lađevac (Lađevac site; $45^{\circ} 06^{\prime} 00.83^{\prime \prime}$ S, $15^{\circ} 37^{\prime} 17.85^{\prime \prime}$ I, $280 \mathrm{~m}$ a.s.l.), near Slunj (Fig. 1). The stream at Plaški site runs across the meadows and its shallow shores are overgrown with the alder and willow trees. The bottom of the stream is covered with rocks, stones and pebbles with plenty of roots offering a variety of hiding places for crayfish. The stream at Lađevac site flows through deciduous forest. The bottom of the stream is covered with stones, pebbles, sand and mud and its relatively high shores offer to crayfish ideal substrate for digging the holes to hide.

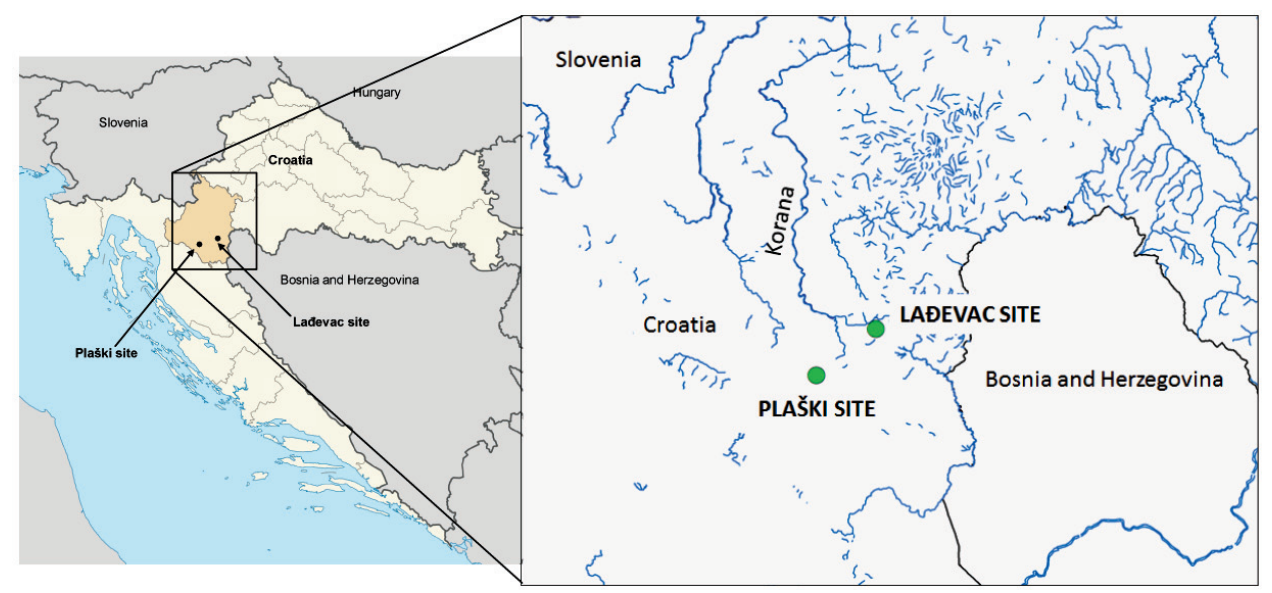

Fig. 1. Position of the study sites on the map of Croatia 
Crayfish were trapped once a month using handmade traps that were exposed at approximately $10 \mathrm{~m}$ intervals along the banks, placed under stones and tree roots or fixed to the bottom. Traps were made of two PVC bottles $(1.5 \mathrm{~L})$ that were coupled together and funnel entrances (made of plastic net, mesh size $2 \mathrm{~mm}$ ) were attached at both ends. Traps were baited with fish, pieces of sausages or chicken liver and left in the water overnight.

Trapped crayfish were checked for sex, moulting state, limb loss, injuries and signs of diseases. Females were checked for reproductive status: glair glands, presence of attached spermatophores, eggs or hatched juveniles were recorded. Pleopodal eggs were counted, diameter of 3 randomly chosen eggs was measured and average egg diameter was calculated. Weight (WEIG) was measured using dynamometer (Pesola $300 \mathrm{~g}$ ). Seven morphometric characteristics were recorded using Vernier calliper (accuracy of $0.1 \mathrm{~mm}$ ): total body length (from the tip of the rostrum to the end of the telson, TBL), carapace length (from the postorbital edge to the postlateral end, CARL), carapace width (in the areolar area, CARW), claw length (CLAL), claw width (CLAW), claw height (CLAH) and width of the first abdominal pleura (WFAP). After examination and measurement, animals were released back into the water. For each sampling occasion, water temperature, conductivity, $\mathrm{pH}$, oxygen concentration, nitrates concentration, phosphates concentration, stream velocity and water level were recorded in the field, while water hardness was measured in the laboratory (APHA, 1985).

Basic statistics was performed to describe measured physicochemical parameters of water. Spearman's correlation factors between the number of animals caught and physicochemical parameters of water were determined. Sex ratio (males:females) for both populations was calculated. Spearman's correlation factors between females total body length and number and diameter of pleopodal eggs were determined. Proportion of animals that suffered from some kind of body damage or disease was also calculated. Normality of data distribution for each morphometric measurement was tested using Shapiro-Wilks W test. In order to avoid comparison of young and adult crayfish, animals with total body length smaller than $60 \mathrm{~mm}$ were excluded from further analysis (size limit was set with regard to the observations made by MAGUIRE \& KLOBUČAR, 2011). Basic statistics was performed to describe morphometric measures of adult crayfish for each population separately. In order to minimize effects of size, all morphometric measurements were converted to ratio of carapace length (CHAmbers et al., 1979; Sint et al., 2005). T-test between sexes was performed in order to determine whether males and females differ significantly in measured morphometric values. T-test between two populations for males and females separately was performed in order to determine whether the crayfish from the two populations differed significantly in measured morphometric values. Statistical analyses were performed using Statistica 8 for Windows (StatSoft, Inc.).

\section{RESULTS}

Statistically described physicochemical parameters of water in both study sites are given in Tab. 1.

\section{LAĐEVAC SITE}

We caught 383 animals in total (203 males and 180 females, sex ratio was 1.13:1). Number of animals caught fluctuated throughout the year corresponding to expected 
Tab. 1. Physicochemical parameters of water and average flow speed of the studied sites.

\begin{tabular}{|l|c|c|c|c|}
\hline & \multicolumn{2}{|c|}{ Lađevac site } & \multicolumn{2}{c|}{ Plaški site } \\
\hline characteristic & range & mean $\pm \mathrm{SD}$ & range & mean $\pm \mathrm{SD}$ \\
\hline temperature $\left({ }^{\circ} \mathrm{C}\right)$ & $6-16.5$ & $11.86 \pm 3.24$ & $8-16$ & $12.61 \pm 2.92$ \\
\hline $\mathrm{pH}$ & $7.71-8.19$ & $7.94 \pm 0.14$ & $7.85-8.26$ & $8.11 \pm 0.1$ \\
\hline conductivity $\left(\mu \mathrm{Scm}^{-1}\right)$ & $358-438$ & $409.11 \pm 25.36$ & $378-441$ & $414 \pm 18.44$ \\
\hline $\mathrm{O}_{2}\left(\mathrm{mgL}^{-1}\right)$ & $9.31-12.9$ & $11.1 \pm 1.08$ & $9.97-11.8$ & $10.86 \pm 0.52$ \\
\hline nitrates $\left(\mathrm{mgL}^{-1}\right)$ & $0.31-0.864$ & $0.491 \pm 0.148$ & $0.06-0.81$ & $0.556 \pm 0.181$ \\
\hline phosphates $\left(\mathrm{mgL}^{-1}\right)$ & $0.011-0.049$ & $0.019 \pm 0.011$ & $0.01-0.08$ & $0.032 \pm 0.021$ \\
\hline total hard. $\left(\mathrm{mgCaCO}_{3} \mathrm{~L}^{-1}\right)$ & $189-248$ & $218 \pm 17$ & $193-247$ & $221 \pm 14$ \\
\hline aver. flow speed $\left(\mathrm{cms}^{-1}\right)$ & \multicolumn{3}{|c|}{7.71} & \multicolumn{2}{c|}{17.71} \\
\hline
\end{tabular}

crayfish year cycle (Fig. 2): males were more active and therefore more frequently caught during the time when females were berried, and females were more frequently caught after hatching and before mating. We found positive correlations between the number of animals caught and water temperature $(r=0.589)$, conductivity $(r=0.596)$ and water hardness $(r=0.552)$. Negative correlation was found between the number of animals

Tab. 2. Appearance of some physiological functions per month for the two studied populations.

\begin{tabular}{|c|c|c|c|c|c|c|c|c|c|c|c|c|}
\hline \multirow[t]{2}{*}{ function } & \multicolumn{12}{|c|}{ month } \\
\hline & 1 & 2 & 3 & 4 & 5 & 6 & 7 & 8 & 9 & 10 & 11 & 12 \\
\hline \multicolumn{13}{|l|}{ Lađevac site } \\
\hline activity & + & + & + & + & + & + & + & + & + & + & + & + \\
\hline moulting & & & & & & + & + & + & + & + & & \\
\hline glair glands & & & & & & & & + & + & + & & \\
\hline yellow eggs & & & & & & & & + & + & & & \\
\hline brown eggs & & & & & & & & & + & + & & \\
\hline pleopodal eggs & + & + & + & + & + & + & & & & & + & + \\
\hline juveniles & & & & & & + & + & & & & & \\
\hline \multicolumn{13}{|l|}{ Plaški site } \\
\hline activity & + & + & + & + & + & + & + & + & + & + & + & + \\
\hline moulting & & & & & + & + & + & + & + & + & & \\
\hline glair glands & & & & & & & + & + & + & + & & \\
\hline yellow eggs & & & & & & & & + & + & & & \\
\hline brown eggs & & & & & & & & & + & + & & \\
\hline pleopodal eggs & + & + & + & + & + & + & & & & & + & + \\
\hline juveniles & & & & & & + & & & & & & \\
\hline
\end{tabular}




\section{Lađevac}

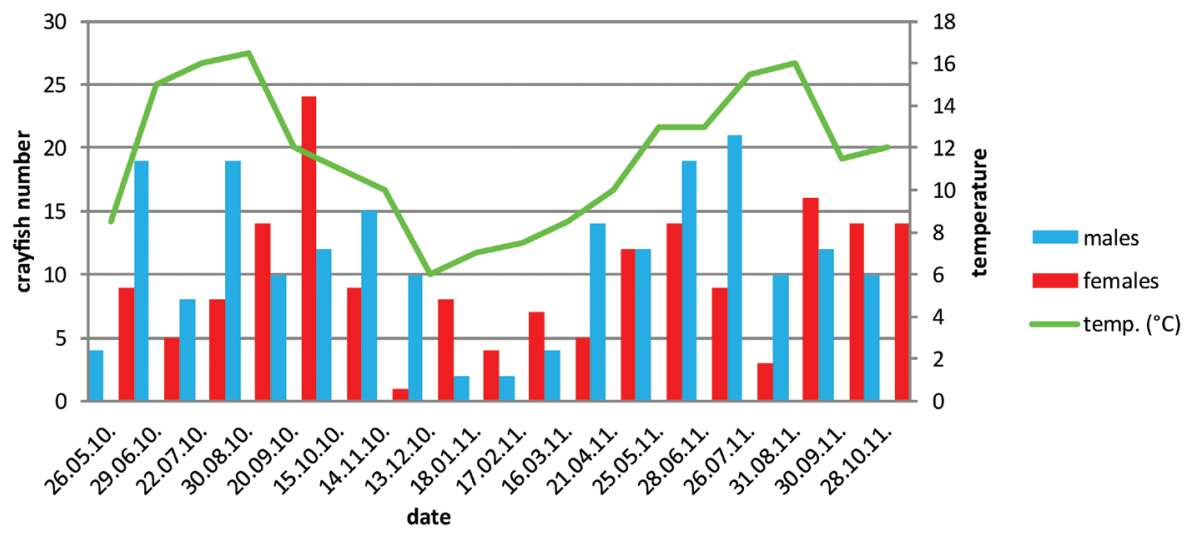

Fig. 2. Relationship between numbers of A. torrentium caught in Lađevac site (Slunj) per month and water temperature

caught and water level $(\mathrm{r}=-0.56)$. The maximal recorded weight for males was $72 \mathrm{~g}$ and for females $43 \mathrm{~g}$, while the maximal recorded body length for males was $11.02 \mathrm{~cm}$ and for females $10.37 \mathrm{~cm}$. The majority $(78.8 \%)$ of captured crayfish had a total body length between 6 and $10 \mathrm{~cm}$. Freshly moulted animals were caught from June to October (Tab. 2). Development of the glair glands in females was recorded from August to October. Yellow, ovarian eggs were recorded in August and September, brown eggs in September and October and external eggs from November to June next year. Newly hatched juveniles were caught in June and July. Out of 180 females trapped, 43 (23.89\%) were found with pleopodal eggs. The smallest female carrying eggs was $6.94 \mathrm{~cm}$ long. The mean diameter of pleopodal eggs was $2.52 \mathrm{~mm}$ (ranged from 2.16 to $2.97 \mathrm{~mm}$ ) and mean number of eggs per female was 92.81 (ranged from 19 to 141). No statistically significant correlation between females length and number or diameter of pleopodal eggs was recorded. Nearly one quarter $(23.02 \%)$ of examined crayfish suffered from some kind of body damage (cheliped or limb loss, damaged rostrum, telson etc), $12.44 \%$ had signs of burn spot disease and on $11.9 \%$ of crayfish caught we found epibionts Branchiobdella sp.

\section{PLAŠKI SITE}

We caught 427 animals in total (241 males and 186 females, sex ratio was 1.29:1). Similar to the Lađevac site, number of animals caught fluctuated throughout the year corresponding to expected crayfish year cycle (Fig. 3). We found positive correlation between the number of animals caught and the water temperature $(r=0.68)$. The maximal recorded weight for males was $61 \mathrm{~g}$ and for females $38 \mathrm{~g}$, while the maximal recorded body length for males was $10.32 \mathrm{~cm}$ and for females $9.59 \mathrm{~cm}$. The majority $(88.68 \%)$ of captured crayfish had a total body length between 6 and $10 \mathrm{~cm}$. Freshly moulted animals were caught from June to November (Tab. 2). Development of the glair glands in females started in July and ended in October. Yellow, internal eggs were recorded in August and September, brown eggs in September and October and external from November to June. Newly hatched juveniles were caught in June. Out of 186 females tra- 


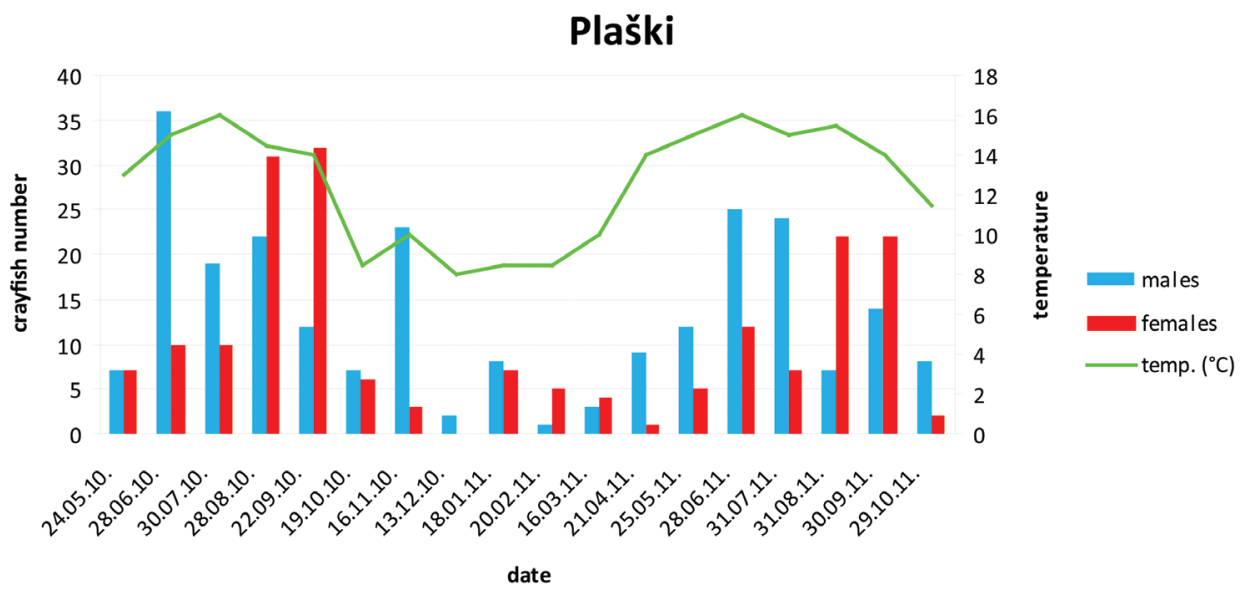

Fig. 3. Relationship between numbers of $A$. torrentium caught in Plaški site per month and water temperature

pped, 19 (10.22\%) were found with external eggs. The smallest female carrying eggs was $6.42 \mathrm{~cm}$ long. The mean diameter of pleopodal eggs was $2.55 \mathrm{~mm}$ (ranged from 2.25 to 3.14) and mean number of eggs per female was 67.7 (ranged from 6 to 110). A negative correlation between number of pleopodal eggs and their diameter was recorded $(\mathrm{r}=$ $-0.65)$. Nearly one third (30.05\%) of the crayfish suffered from cheliped or limb loss or some other kind of injury, $11.14 \%$ had signs of burn spot disease and on $6.35 \%$ of animals caught we found epibionts Branchiobdella sp.

Normal probability plots have shown normal distribution for all of the morphometric measurements, in both populations. Results of descriptive statistics for morphometric measures are shown in Tab. 3. T-test between sexes showed that males and females, from both populations, differ significantly in all measured morphometric characteristics and body weight (Tab. 4). T-test between populations showed that males from Lađevac and Plaški sites differed the most in CARW, CLAL, CLAW and CLAH (Tab. 5), and for females in TBL, CARW, CLAH and WFAP (Tab. 6).

\section{DISCUSSION}

Both studied Austropotamobius torrentium populations are of the natural origin. Physical and chemical characteristics of water are important factors influencing crayfish population abundance and activities throughout the year. In studied streams, water temperature fluctuated throughout the year, with average values somewhat higher at Plaški site (Tab. 1). In both streams we found positive correlation between the number of animals caught and water temperature, but we could not state that crayfish activity is only and directly linked to water temperature (Figs 2 and 3) since the crayfish activity did not increase proportionally to temperature increase. It seems that the temperature increase in spring initiates crayfish activity: the animals metabolic and locomotion rates also raises and it is likely that the trappability is higher at higher temperatures (ACKEFORS, 1999). According to Troschel \& Dehus (1993), A. torrentium is not active when the water temperature falls below $5{ }^{\circ} \mathrm{C}$. Maguine et al. (2002) did not record any activity when the 
Tab. 3. Results of descriptive statistics for morphometric measures and weight of adult crayfish (males and females) in both populations. (TBL=total body length, $C A R L=$ carapace length, $\mathrm{CARW}=$ carapace width, $\mathrm{CLAL}=$ claw length, $\mathrm{CLAW}=$ claw width, $\mathrm{CLAH}=$ claw height, WFAP=width of the first abdominal pleura, WEIG=weight)

\begin{tabular}{|c|c|c|c|c|c|c|c|c|}
\hline & \multicolumn{8}{|c|}{ Lađevac site } \\
\hline & \multicolumn{4}{|c|}{ Males } & \multicolumn{4}{|c|}{ Females } \\
\hline & Mean & Minimum & Maximum & St. dev. & Mean & Minimum & Maximum & St. dev. \\
\hline TBL & 83.78 & 60.17 & 110.22 & 12.73 & 80.45 & 61.19 & 103.74 & 7.91 \\
\hline CARL & 38.48 & 24.89 & 51.62 & 6.67 & 34.90 & 25.82 & 45.56 & 3.62 \\
\hline CARW & 22.91 & 14.85 & 32.53 & 4.43 & 20.32 & 14.62 & 29.28 & 2.28 \\
\hline CLAL & 35.08 & 17.46 & 59.85 & 10.14 & 26.29 & 17.46 & 38.84 & 4.00 \\
\hline CLAW & 16.51 & 8.88 & 26.66 & 4.45 & 12.60 & 8.31 & 16.80 & 1.76 \\
\hline CLAH & 8.98 & 5.04 & 15.75 & 2.39 & 6.78 & 3.91 & 8.89 & 0.95 \\
\hline WFAP & 19.74 & 13.28 & 25.86 & 3.06 & 20.90 & 11.20 & 28.69 & 2.70 \\
\hline \multirow[t]{4}{*}{ WEIG } & 30.79 & 5.00 & 72.00 & 14.96 & 21.98 & 11.00 & 43.00 & 5.82 \\
\hline & \multicolumn{8}{|c|}{ Plaški site } \\
\hline & \multicolumn{4}{|c|}{ Males } & \multicolumn{4}{|c|}{ Females } \\
\hline & Mean & Minimum & Maximum & St. dev. & Mean & Minimum & Maximum & St. dev. \\
\hline TBL & 82.92 & 60.15 & 103.20 & 11.33 & 79.18 & 61.72 & 95.98 & 7.84 \\
\hline CARL & 38.12 & 24.31 & 49.87 & 6.07 & 34.66 & 26.43 & 43.79 & 3.75 \\
\hline CARW & 22.36 & 14.92 & 38.45 & 3.91 & 19.94 & 15.01 & 26.69 & 2.28 \\
\hline CLAL & 35.73 & 13.34 & 52.96 & 9.27 & 26.27 & 17.70 & 35.99 & 4.08 \\
\hline CLAW & 16.73 & 9.35 & 23.82 & 3.93 & 12.68 & 7.95 & 17.13 & 1.80 \\
\hline CLAH & 9.29 & 4.69 & 13.52 & 2.19 & 6.97 & 4.09 & 9.13 & 1.03 \\
\hline WFAP & 19.59 & 13.44 & 24.45 & 2.71 & 20.33 & 14.94 & 27.12 & 2.43 \\
\hline WEIG & 30.11 & 9.00 & 61.00 & 12.99 & 21.02 & 9.00 & 38.00 & 6.02 \\
\hline
\end{tabular}

water temperature was below $6.2^{\circ} \mathrm{C}$. In studied streams temperature did not fall below $6{ }^{\circ} \mathrm{C}$ and similar to MAGUiRe \& KLOBUČAR (2011) we recorded minimal winter activity in both populations (Figures 2 and 3). Recorded $\mathrm{pH}$ values and conductivity (Tab. 1) are in accordance with literature data on freshwaters inhabited with crayfish (BoHL, 1987; Renz \& Breithaupt, 2000; Maguire et al., 2002; PÂrvulescu et al. 2011). The oxygen concentration in both streams was relatively high (Tab. 1) and varied between 9.31 and 12.9 in the Lađevac site and 9.97 and 11.8 in the Plaški site. According to Hogger (1988), freshwaters with oxygen concentration higher than $4 \mathrm{mgL}^{-1}$ are suitable for crayfish life. PÂrvulescu et al. (2011) assessed water quality requirements of $A$. torrentium and found that the mean value of dissolved oxygen is $8.93 \pm 0.7 \mathrm{mgL}^{-1}$, which is below values recorded in examined streams. As the stone crayfish prefers waters with low to moderate organic pollution (P̈̈скL, 1998), low concentration of nitrates and phosphates recorded in studied streams is in accordance with previous findings (PÂRvUlescu et al. 2011). The 
Tab. 4. Results of the t-test between sexes (statistically significant results are bolded). (abbreviations as in Tab. 3)

\begin{tabular}{|c|r|c|}
\hline variable & t-value & $\mathrm{p}$ \\
\hline TBL & -21.2388 & 0.000000 \\
\hline CARW & 6.1882 & 0.000000 \\
\hline CLAL & 22.3931 & 0.000000 \\
\hline CLAW & 22.0115 & 0.000000 \\
\hline CLAH & 20.4348 & 0.000000 \\
\hline WFAP & -41.1797 & 0.000000 \\
\hline WEIG & 10.7768 & 0.000000 \\
\hline
\end{tabular}

Tab. 5. Results of t-test between populations for males and females (statistically significant results are bolded). (abbreviations as in Tab. 3)

\begin{tabular}{|l|c|c|c|c|}
\hline \multirow{2}{*}{ variable } & \multicolumn{2}{c|}{ males } & \multicolumn{2}{c|}{ females } \\
\cline { 2 - 5 } & $\mathrm{t}$-value & $\mathrm{p}$ & $\mathrm{t}$-value & $\mathrm{p}$ \\
\hline TBL & 0.15618 & 0.875977 & 3.49723 & 0.000529 \\
\hline CARW & 2.76550 & 0.005962 & 2.99741 & 0.002910 \\
\hline CLAL & -2.37381 & 0.018111 & -1.15932 & 0.247099 \\
\hline CLAW & -2.37698 & 0.017956 & -2.22907 & 0.026431 \\
\hline CLAH & -3.66891 & 0.000279 & -3.84721 & 0.000141 \\
\hline WFAP & -0.54713 & 0.584609 & 2.77639 & 0.005782 \\
\hline WEIG & 0.55601 & 0.578536 & 0.11186 & 0.910996 \\
\hline
\end{tabular}

most important element for crayfish growth is calcium in its carbonate and bicarbonate salts (ReYnolds, 2002). Water hardness (expressed as $\mathrm{mg} \mathrm{CaCO}_{3} \mathrm{~L}^{-1}$ ) varied from 189 to 248 , and these values are higher than literature data on the stone crayfish (MAGuire et al., 2002), but still expected due to the geology of the studied area (karst). Average flow speed in the Lađevac site was $7.71 \mathrm{cms}^{-1}$, while in the Plaški site it was a bit higher, 17.71 $\mathrm{cms}^{-1}$. As the stone crayfish prefers water velocities between 0 and $5 \mathrm{cms}^{-1}$ and probability of crayfish presence decreases with increasing water velocity (STREISSL \& HöDL, 2002a), negative correlation found in the Plaški site between the number of animals caught and stream velocity $(\mathrm{r}=-0.48)$ was expected.

The sex ratio in catch was a bit higher in the Plaški site (1.29:1) than in the Lađevac site (1.13:1). Maguire et al. (2002) and Sint et al. (2006) found the sex ratio to be close to 1 in all populations they studied, similarly was found by Huber \& Schubart (2005) who found the sex ratio to be 1.18:1.

The maximal recorded length of crayfish in studied populations was slightly higher than usually recorded for stone crayfish $(11.02 \mathrm{~cm}$ for males and $10.37 \mathrm{~cm}$ for females). VLACH et al. (2009) recorded maximal body length to be $10.5 \mathrm{~cm}$ for males and $9.4 \mathrm{~cm}$ for females, Huber \& Schubart (2005) measured the largest body length to be $9.8 \mathrm{~cm}$ for 
males and $9 \mathrm{~cm}$ for females, while Maguire et al. (2002) recorded maximal length of 10.3 for males and $9.28 \mathrm{~cm}$ for females. MaGuire \& KLOBUČAR (2011) found the majority of captured crayfish to be of a total body length between 5 and $8 \mathrm{~cm}$, while we found that $78.8 \%$ of captured crayfish in Lađevac site and $88.68 \%$ in Plaški site had total body length between 6 and $10 \mathrm{~cm}$. It is known that when the traps are used as catching gear, adult animals prevail in catch (GHERARd et al., 1996; GrANDJEAN et al., 2000), so the results obtained probably underestimates smaller size classes, even though traps we used are not size selective. Growth and moulting process in crayfish is influenced by abiotic factors (temperature, dissolved oxygen, $\mathrm{pH}$, nutrient levels, water quality and habitat composition) and biotic factors (food availability, predation, population density, age and maturity status). Crayfish growth takes place only above a certain temperature and increases with rise of temperature up to a species specific optimum (REYNOLDS, 2002). Previous studies of stone crayfish populations in Croatia (MAguire et al., 2002) found moulting process starting in May and June and we recorded the same timing: moulting in the Lađevac site started in June and in the Plaški site in May and freshly moulted stone crayfish were found until October in both populations. Since STREISSL \& HöDL (2002a) observed moulting process in Austrian stone crayfish populations to begin in late June and end in the end of August, one may conclude that moulting period in Croatian population is considerably longer, and possibly a consequence of differences in climate.

The glair glands in females started to develop from the end of July in Plaški and the end of August in Lađevac, what is similar to observations made by MAGuire et al. (2002). According to AcKefors (1999) development of glair glands in Astacus astacus depends on female's nutritional status, so earlier start of development of glair glands found in Plaški may indicate that the conditions in that stream support optimal females' nutritional status. Total length of sexually mature females are similar to data collected for stone crayfish in other European regions: STREISSL \& HöDL (2002b) recorded the smallest ovigerous female to have a total length of $6.1 \mathrm{~cm}$, and similar was found by Hubenova et al. (2010) $(6.2 \mathrm{~cm}$ and $6.4 \mathrm{~cm})$. Freshwater crayfish have low fecundity, usually with fewer than 250 eggs (Laurent, 1988; Reynolds, 2002; Policar, 2004). Fecundity is proportional to female body size and number of eggs per female may differ significantly due to environmental conditions (SKurdal \& Taugbol, 2002). Maguire et al. (2005) recorded the average number of pleopodal eggs to be 62.63 per female (range from 30 to 104), with their average diameter to be $2.8 \mathrm{~mm}$ (range from 2.4 to $3.4 \mathrm{~mm}$ ). Hubenova et al. (2010) studied two populations and recorded average number of eggs to be 78 and 29, with an average diameter of 2.8 and $3.2 \mathrm{~mm}$. We recorded the average number of pleopodal eggs to be slightly higher in Lađevac (92.81), but the number of eggs per female varied greatly in both populations: we found females with less than 10 eggs (what is probably consequence of egg loss) and more than 140 eggs. We also found lower values of the average egg diameter in both populations studied (2.52 in Lađevac and 2.55 in Plaški), with maximum value of $3.14 \mathrm{~mm}$. While MAguire et al. (2005) and Huner \& LINDQUisT, 1991 found positive correlation between female body size and number of pleopodal eggs, we found positive correlation between female body size and average diameter of eggs in Lađevac and negative correlation between number of pleopodal eggs and their average diameter in Plaški.

Relatively high proportion (23.02\% in Lađevac and 30.05\% in Plaški) of examined crayfish suffered from some kind of body damage (cheliped or limb loss, damaged rostrum, telson etc). The proportion of damaged crayfish in a population could be indicator of violation by predators (BоHL, 1997), consequence of problems during moulting 
period or aggressive behaviour during the mating period (MAGuire et al., 2002). The proportion of crayfish recorded with symptoms of burn spot disease (12.44\% in Lađevac and $11.14 \%$ in Plaški) and epibiont clitellat worm Branchiobdella sp. (11.9\% in Lađevac and $6.35 \%$ in Plaški) was lower than previously recorded in Croatian stone crayfish populations (MAGUiRe et al., 2002).

Freshwater crayfish are known to show sexual dimorphism after attaining maturity that is seen in allometrical growth of males' claws and abdomens in females (STREISSL \& HöDL, 2002a). Adult males and females in studied populations differ significantly in measured morphometric characteristics, following the expected form of allometrical growth: all of the measures taken are higher in males, except the width of the first abdominal pleura, which is higher in females.

It is well known that differences in crayfish morphology may occur between distinct populations as adaptation to local environmental conditions (CHAMBERs et al., 1979; Grandjean \& Souty-Grosset, 2000). Studied populations (both males and females) differ significantly in four measured morphometric characteristics: males from Lađevac have larger carapace width, while males from Plaški have larger claw length, width and height, females from Lađevac have larger total body length, carapce width and width of the first abdominal pleura, while females from Plaški have larger claw width (Tab. 3). Since habitat characteristics in two studied streams are different, it could be assumed that morphological differences between populations occurred due to crayfish adaptation to specific local environmental and ecological conditions. In order to confirm such assumption, further analyses, with larger number of morphometrical characteristics and molecular markers of the two studied populations should be conducted.

\section{ACKNOWLEDGEMENTS}

We would like to thank to Milica Kraguljac, Zdravko Vukošić and Stjepan Perković for their help during the field investigation.

Received September 7, 2015

\section{REFERENCES}

AcKefors, H.E.G., 1999: Observations on the yearly life cycle of Astacus astacus in a small lake in Sweden. Freshwater crayfish, 12, 413-429.

Albrecht, H., 1982: Das System der europäischen Flußkrebse (Decapoda, Astacidae): Vorschlag und Begründung. Mitt. Hamb. Zool. Mus. Inst., 79, 187-210.

APHA, 1985: Standard methods for the examination of water and wastewater. $16^{\text {th }}$ ed. Amer. Publ. Health Assoc., New York.

Begg, G.A., Friedland, K.D. \& Pearce, J.P., 1999: Stock identification and its role in stock assessment and fisheries management: an overview. Fish. Res. 43, 1-8.

Boнl, E., 1987: Comparative studies on crayfish brooks in Bavaria (Astacus astacus L., Austropotamobius torrentium Schr.). Freshwater crayfish 7, 287-294.

BонL, E., 1997: An isolated population of the white-clawed crayfish (Austropotamobius pallipes) in the principality of Liechtenstein. Bull. Fr. Pêche Piscic., 347, 701-712.

Budinna, N., 1991: Umetna inkubacija rakovih jajčec vrste Astacus astacus (L.). Ichthyos, 10, 1-17.

CAPELli, G.M. \& Magnusson, J.J., 1975; Reproduction, moulting and distribution of Orconectes propinquua (Girard) in relation to temperature in a north mesotrophic lake. Freshwater crayfish, 2, 415-427.

Chambers, C.L., Payne, J.F. \& Kennedy, M.L., 1979: Geographic variation in the dwarf crayfish, Cambarellus puer Hobbs (Decapoda, Cambaridae). Crustaceana 36, 39-55. 
Gherardi, F., Villanelli, F. \& Dardi, P., 1996: Bihevioral ecology of the white-clawed crayfish, Austropotamobius pallipes, in a Tuscan stream: preliminary results. Freshwater crayfish, 11, 182-194.

Gottstein, S., Hudina, S., Lucić, A., Maguire, I., Ternjej. I. \& Žganec, K., 2011: Crveni popis rakova (Crustacea) slatkih i bočatih voda Hrvatske, Državni zavod za zaštitu prirode, Zagreb, Croatia.

Grandjean, F., Cornuault, B., Archambault, S., Bramard, M. \& Otrebsky, G., 2000: Life history and population bioogy of the white clawed crayfish, Austropotamobius pallipes pallipes, in a brook from the Poitou-Charentes region (France). Bull. Fr. Pêche Piscic., 356, 55-70.

Grandjean, F. \& Souty-Grosset, C., 2000: Genetic and morphological variation in the endangered crayfish species, Austropotamobius pallipes (Lereboullet) (Crustacea, Astacidae) from the Poitou-Charentes region (France). Aquatic Sciences, 62, 1-19.

Grandjean, F., Romain, D., Avila-Zarza, C., Bramard, M., Souty-Grosset, C. \& Mocquard, J.P., 1997a: Morphometry, sexual dimorphism and size at maturity of the whiteclawed crayfish Austropotamobius pallipes pallipes (Lereboullet) from a wild French population at Deux-Se'vres (Decapoda, Astacidea). Crustaceana 70, 31-44.

Grandjean, F., Romain, F., Souty-Grosset, C. \& Mocquard, J.P., 1997b: Size at sexual maturity and morphometric variability in three populations of a Austropotamobius pallipes pallipes (Lereboullet, 1858) according to a restocking strategy. Crustaceana 70, 454-468.

HogGer, J.B., 1988: Ecology, population biology and behaviour. In: Holdich, D.M. \& Lowery, R.S. (eds.), Freshwater crayfish: Biology, Management and Exploitation. Croom Helm, London. p. 115-144.

Hubenova, T., Vasileva, P. \& Zaikov, A., 2010: Fecundity of stone crayfish Austropotamobius torrentium from two different populations in Bulgaria. Bulg. J. Agric. Sci., 16, 387-393.

Huber, M.G.J. \& Schubart, C.D., 2005: Distribution and reproductive biology of Austropotamobius torrentium in Bavaria and documentation of a contact zone with the alien crayfish Pacifastacus leniusculus. Bull. Fr. Pêche Piscic., 376-377, 759-776.

HunER, J.V. \& LindQvist, O.V., 1991: Special problems in freshwater crayfish egg production. In: WenNeR, A. \& KunIs, A. (eds.), Crustacean egg production. A.A. Balkema, Roterdam. p. 235-246.

Imre, I., Mcloughlin, R.L. \& NoAkes, D.G.L., 2002: Phenotypic plasticity in brook charr: changes in caudal fin induced by water flow. J. Fish Biol. 61, 1171-1181.

Kappus, B., Peissner, T. \& Rawer-Jost, C., 1999: Distribution and habitat conditions of crayfish populations in the urban freshwater systems of Stuttgart (Baden-Württemberg, Germany). Freshwater Crayfish, 12, 778-785.

Karaman, S., 1929: Die Potamobiiden Jugoslaviens. Glasnik zemaljskog muzeja u Bosni i Hercegovini XLI, 147-150

Laurent, P.J., 1988: Austropotamobius pallipes and A. torrentium with observations on their interactions with other species in Europe. In: Holdich, D.M. \& Lowerr, R.S. (eds.), Freshwater crayfish: biology, management and exploitation. Croom Helm, London. p. 341-364.

Lodge, D.M. \& Hill, A.M., 1994: Factors governing species composition, population size and productivity of cool water crayfishes. Nord. J. Freshw. Res. 69, 111-136.

MAchino, Y. \& FÜreder, L., 2005: How to find a stone crayfish Austropotamobius torrentium (Schrank, 1803): a biogeography study in Europe. Bull. Fr. Pêche Piscic. 376-377, 507-517.

Maguire, I., 2002: Porodica Astacidae u sjeverozapadnoj Hrvatskoj, Doctoral thesis, University of Zagreb, 128 p. (in Croatian with English abstract).

Maguire, I., Erben, R., Klobučar, G.I.V. \& Lajtner, J., 2002: Year cycle of Austropotamobius torrentium (Schrank) in streams on Medvednica mountain (Croatia). Bull. Fr. Pêche Piscic., 367, 943-957.

Maguire, I. \& Gottstein-Matočec, S., 2004: The distribution pattern of freshwater crayfish in Croatia. Crustaceana 77(1), 25-49.

Maguire, I., Klobučar, G.I.V. \& Erben, R., 2005: The relationship between female size and egg size in the freshwater crayfish Austropotamobius torrentium. Bull. Fr. Pêche Piscic., 376-377, 777-785.

Maguire, I., Klobučar, G., Faller, M., Machino, Y., Kucinic, M. \& Zuzul, M., 2006: Updates on the distribution of the white-clawed and the narrow-clawed crayfish in Croatia. Crayfish news, 28, 4-5.

Maguire, I. \& DAKIĆ, L., 2011: Comparative analyses of Astacus leptodactylus morphological characteristics from Croatia and Armenia. Biologia 66/3, 491-498.

Maguire, I. \& Klobučar. G., 2011: Size structure, maturity size, growth and condition index of stone crayfish (Austropotamobius torrentium) in North-West Croatia. Knowledge and Management of Aquatic Ecosystems, 401, 12. 
Maguire, I., Jelić, M. \& Klobučar, G., 2011: Update on the distribution of freshwater crayfish in Croatia. Knowledge and Management of Aquatic Ecosystems, 401, 31.

NARODNE NOVINE, 2013: Zakon o zaštiti prirode, No 80.

NARODNE NOVINE, 2013: Pravilnik o strogo zaštićenim vrstama, No 144.

PAKkasma, S., 2001: Morphological differentiation among local trout (Salmo trutta) populations. Biol. J. Linn. Soc., 72, 231-239.

Pârvulescu, L., Pacioglu, O. \& Hamchevici, C., 2011: The assessment of the habitat and water quality requirements of the stone crayfish (Austropotamobius torrentium) and noble crayfish (Astacus astacus) species in the rivers from the Anina Mountains (SW Romania). Knowledge and Management of Aquatic Ecosystems, 03, 401.

PöckL, M., 1998: Verbreitung und Ökologie der in Österreich vorkommenden Flußkrebse. In: EdER, E. \& HödL, W. (eds.) Flußkrebse Österreichs. Stapfia, 58, zugleich Kataloge des OÖ. Landesmuseums, Neue Folge Nr. 137. pp. 119-130.

Policar, T., 2004: PhD thesis completed. Crayfish news, 2, 24-25.

Renz, M. \& Breithaupt, T., 2000: Habitat use of the crayfish Austropotamobius torrentium in small brooks and in Lake Constance, Southern Germany. Bull. Fr. Pêche Piscic., 356, 139-154.

Reynolds, J.D., 2002: Growth and reproduction. In: Holdich, D.M. (ed.) Biology of freshwater crayfish. Blackwell science, Oxford. p. 152-192.

Schulz, N. \& Kirchlehner, W., 1984: Der Steinkrebsbestand Astacus torrentium (Schrank) im Spintikbach (Kärnten, Österreich). Österreichs Fischerei 37, 47-57.

Sint, D., Dalla Via, J. \& Füreder, L., 2005: Morphological variations in Astacus astacus L. and Austropotamobius pallipes (Lereboullet) populations. In: European native crayfish in relation to land-use and habitat deterioration with a special focus on Austropotamobius torrentium, CRAYNET, Vol 4. FürEDER, L. \& Souty Grosset, C. (Eds). Bull. Fr. Pêche Piscic. 376-377, 637-652.

Sint, D., Dalla Via, J. \& Füreder, L., 2006: The genus Austropotamobius in the Ausserfern region (Tyrol, Austria) with an overlap in the distribution of $A$. torrentium and A. pallipes populations. Bull. Fr. Pêche Piscic., 380-381, 1029-1040.

Sint, D., Dalla Via, J. \& Füreder, L., 2007: Phenotypical characterization of indigenous freshwater crayfish populations. J. Zool. 273, 210-219.

Skurdal, J. \& Taugbøl, T., 2002: Astacus. In: Holdich, D.M. (ed.) Biology of freshwater crayfish. Blackwell science, Oxford. p. 467-510.

Stloukal, E. \& Harváneková, M., 2005: Distribution of Austropotamobius torrentium (Decapoda: Astacidae) in Slovakia. Bull. Fr. Pêche Piscic., 376-377, 547-522.

Streissl, F. \& HöDL, W., 2002a: Habitat and shelter requirements of the stone crayfish, Austropotamobius torrentium Schrank. Hydrobiologia 477, 195-199.

STreissl, F. \& HöDl, W., 2002b: Growth, morphometrics, size at maturity, sexual dimorphism and condition index of Austropotamobius torrentium Schrank. Hydrobiologia, 477, 201-208.

Stucki, T. \& Römer, J., 2001: Will Astacus leptodactylus displace Astacus astacus and Austropotamobius torrentium in Lake Ägeri, Switzerland? Aquatic Sciences, 63, 477-489.

Swain, D.P. \& Fооте, C.J., 1999: Stock and chameleons: the use of phenotypic variation in stock identification. Fish. Res. 43, 113-128.

Šulgaj, A., 1937: Rak potočar i njegov uzgoj. In: BAuer, M. (ed.), Monografija, Nova Gradiška, 76 p.

Troschel, H.J. \& Dehus, P., 1993: Distribution of crayfish species in the federal republic of Germany, with special reference to Austropotamobius pallipes. Freshwater crayfish, 9, 390-398.

Vlach, P., Hulec, L. \& Fischer, D., 2009: Recent distribution, population densities and ecological requirements of the stone crayfish (Austropotamobius torrentium) in the Czech Republic. Knowledge and Management of Aquatic Ecosystems, 13, 394-395.

ŽGANEC, K., 2009: Distribution and ecology of epegean fresh and brakish water shrimps (Amphipoda: Gammaroidea) in Croatia, Doctoral thesis, University of Zagreb, 214 p. (in Croatian with English abstract). 


\title{
SUMMARY
}

\section{Year cycle and morphometrical characteristics of Austropotamobius torrentium from two karstic rivers in Croatia}

\author{
L. Dakić \& I. Maguire
}

Austropotamobius torrentium is one of the four native crayfish species inhabiting Croatian freshwater habitats. MaGuire et al. (2011) found decline in number of stone crayfish populations in Croatia. The species is very sensitive to water pollution (MACHINO \& FürEDER, 2005) and habitat deterioration. The aim of this work was to investigate several aspects of species life cycle, morphometrics and habitat parameters. Populations were studied for 18 months in two streams in the Karlovac County and crayfish were trapped once a month. Altogether 806 crayfish were analysed and their weight plus 7 morphometric characteristics were recorded. Eight different physicochemical parameters of the water were measured. Water temperature fluctuated throughout the year, with average value a bit higher in the Plaški site. In both streams we found positive correlation between the number of animals caught and water temperature. The oxygen concentration varied between 9.31 and 12.9 in Lađevac stream and 9.97 and 11.8 in Plaški stream. Water hardness $\left(\mathrm{mg} \mathrm{CaCO}_{3} \mathrm{~L}^{-1}\right)$ varied from 189 to 248, and these values are higher than literature data (MAguire et al., 2002), but still expected due to the geology of the studied area (karst). Average flow speed in Lađevac site was $7.71 \mathrm{cms}^{-1}$, while in Plaški site it was a bit higher, $17.71 \mathrm{cms}^{-1}$. Negative correlation was found in Plaški site between the number of animals caught and stream velocity $(r=-0.48)$. The sex ratio in catch was a bit higher in the Plaški site (1.29:1) than in the Lađevac site (1.13:1). The maximal recorded body length was slightly higher than previously recorded for the stone crayfish (11.02 cm for males and $10.37 \mathrm{~cm}$ for females). Majority of captured crayfish $(78.8 \%$ in Lađevac site and $88.68 \%$ in Plaški site) had total body length between 6 and $10 \mathrm{~cm}$. Previous studies of stone crayfish populations in Croatia (MAGuire et al., 2002) found moulting process starting in May and June and we recorded similar timing: moulting in the Lađevac site started in June and in the Plaški site in May and freshly moulted stone crayfish were found until October in both populations. Moulting process in Austrian populations begins in late June and ends in the end of August (STREISSL \& HöDL, 2002a), so moulting period in Croatian populations is considerably longer. The glair glands started to develop from the end of July. Total body length of the smallest egg bearing female was similar to data collected for the stone crayfish in other European regions. We recorded the average number of pleopodal eggs to be slightly higher in Lađevac (92.81), but the number of eggs per female varied greatly: we found females with less than 10 eggs and more than 140 eggs. We found average egg diameter to be $2.52 \mathrm{~mm}$ in Lađevac and $2.55 \mathrm{~mm}$ in Plaški. Positive correlation between female body size and average diameter of eggs was found in Lađevac and negative correlation between number of pleopodal eggs and their average diameter in Plaški. High proportion (23.02\% in Lađevac and 30.05\% in Plaški) of examined crayfish suffered from some kind of body damage. The proportion of crayfish recorded with symptoms of burn spot disease (12.44 \% in Lađevac and $11.14 \%$ in Plaški) and epibiont clitellat worm Branchiobdella sp. (11.9\% in Lađevac and 6.35\% in Plaški) was lower than previously recorded in Croatian stone crayfish populations (MAguire et al., 2002). Adult males and females in studied populations differ significantly in measured morphometric characteristics, what was expected due to allometrical growth: all of the measures taken are higher in males, except the width of the first abdominal pleura, which is higher in females. Studied populations (both males and females) differ significantly in the four measured morphometric characteristics. 